\title{
SMEs and Bank Lending Relationships: the Impact of Mergers
}

\author{
Hans Degryse \\ (K.U. Leuven, CentER and CESifo) \\ Nancy Masschelein \\ (National Bank of Belgium) \\ Janet Mitchell \\ (National Bank of Belgium, CEPR)
}

This version: December 15, 2004

\begin{abstract}
This paper studies the impact of bank mergers on firm-bank lending relationships using information from individual loan contracts in Belgium. We analyse the effects of bank mergers on the probability of borrowers maintaining their lending relationships and on their ability to continue tapping bank credit. The Belgian financial environment reflects a number of interesting features: high banking sector concentration; "in-market" mergers with large target banks; importance of large banks in providing external finance to SMEs; and low numbers of bank lending relationships maintained by SMEs. We find that bank mergers generate short-term and longer-term effects on borrowers' probability of losing a lending relationship. Mergers also have heterogeneous impacts across borrower types, including borrowers of acquiring and target banks, borrowers of differing size, and borrowers with single versus multiple relationships. Firms borrowing from acquiring banks are less likely to lose their lending relationship, while target bank borrowers are more likely to lose their relationship. Overlap borrowers - borrowing from two of the merging banks - are less likely to lose their relationship than firms borrowing from only one of the merging banks or firms borrowing from nonmerging banks.
\end{abstract}

\footnotetext{
${ }^{*}$ We thank Steven Ongena, Fabio Panetta as well as seminar participants at the 2004 National Bank of Belgium conference "Efficiency and Stability in an Evolving Financial System" and the 2004 CEPR European Summer Symposium in Financial Markets for their comments.
} 


\section{Introduction}

The impact of bank mergers on firm borrowers has been a topic of interest for researchers and policy makers for a number of years. Two questions of general concern have been raised: Do bank mergers harm or benefit bank borrowers? Do bank mergers result in less credit for small firms? (For an overview see Berger et al., 1999.) In many countries banks are the most important providers of external finance to firms. Banks are especially important for small and medium size firms, as they represent these firms' principal source of external finance.

Consolidation in banking sectors in countries around the world has further motivated the recent focus on the impacts of bank mergers. Belgium is no exception in this regard. A wave of bank mergers during the past decade has decreased the total number of banks operating in Belgium and has increased banking sector concentration. In this paper we use data on firm-bank loan contracts from the Belgian credit register to analyse the impact of bank mergers on the bank lending relationships of small and medium size firms (SMEs). Although the literature on the impact of bank mergers on borrowers is growing, very few studies to date have made use of firmlevel data.

Investigations that have relied on firm-level data to study the effects of bank mergers have been undertaken for two other countries: Italy (see Bonaccorsi di Patti and Gobbi, 2003; Chionsini et al, 2004; Sapienza, 2002; Panetta et al, 2004) and Norway (Karceski et al, 2004). ${ }^{1}$ Like ours, the Italian studies use credit register data and focus on SMEs. ${ }^{2}$ In contrast, Karceski et al use data on Norwegian firms' stock market returns to study the effects of bank mergers on borrowers; therefore, their focus is on large, listed firms.

The context of our analysis differs in a number of ways from the settings of the existing studies. First, concentration in the Belgian banking sector has increased significantly and is now very high as a result of a number of major "in-market" bank

\footnotetext{
${ }^{1}$ Scott and Dunkelberg (2003) address bank mergers in the US also using firm-level data.

${ }^{2}$ Banks must report to the Belgian credit register information relating to total exposures above $€$

25.000. The reporting requirement for the Italian credit register is about $€ 75.000$.
} 
mergers. Second, unlike Italian SMEs, Belgian SMEs generally maintain low numbers of bank lending relationships, which actually appears to be more typical of SMEs in other countries than the mean number of nine lending relationships reported by Sapienza (2002) for Italian SMEs. Third, large banks are very important in lending to SMEs in Belgium. Finally, the mergers that we study all involve large target banks, as well as the more typical feature of large acquiring banks.

We tackle new questions, in addition to investigating questions that other authors have addressed. Among the questions that have been studied in other papers are the following. Is the probability of losing a bank lending relationship higher for borrowers of merging banks than for borrowers of nonmerging banks? Are particular borrowers affected more by mergers than others (e.g., small vs. large firms; borrowers of acquiring vs. target banks)? How are merger effects spread out over time? Do mergers affect the interest rates offered to continuing borrowers? ${ }^{3}$

New questions that we address include: Are overlap borrowers - borrowers of both merging banks - affected differently by mergers than borrowers of only one of the merging banks? Are borrowers with single bank relationships affected differently than borrowers with multiple relationships? Informational gains from combining the assessments of two banks may imply that overlap borrowers are affected differently by mergers than borrowers of only one of the merging banks. The Belgian context may help to identify this effect, as the number of lending relationships maintained by firms is low. Firms with single relationships can be expected to have lower bargaining power (or higher switching costs) than firms with multiple relationships; therefore, single-relationship borrowers of merging banks may benefit less from (or be harmed more by) bank mergers.

The economic literature in general and the banking literature in particular have argued that mergers produce efficiency gains but also increase market power (for an overview on bank mergers, see Focarelli et al, 2002). Can we expect that market power effects are more important than efficiency gains? Sapienza's (2002) results on loan rates for firms continuing to borrow from the merged bank after the merger 
suggest that market power effects may dominate for "in-market" mergers. The question remains as to whether the same conclusion holds with respect to termination of bank lending relationships.

Previous studies have found that bank mergers have heterogeneous impacts on borrowers with differing characteristics. In particular, small firm borrowers of merging banks appear to face additional difficulties in tapping credit in the short run following a merger. Also, borrowers of target banks (especially small target banks when the acquiring bank is large) seem to be harmed more by mergers. These results suggest the importance of supply effects. Karceski et al (2004), however, argue they may also highlight demand effects as they suggest that target bank borrowers with lower switching costs are less harmed than those with higher switching costs.

The structure of the Belgian banking market, where large banks were important in granting loans to small firms even before the mergers, might suggest that other studies' findings of stronger merger effects for small firms than for large firms will not hold for our analysis. In addition, the fact that the target banks are large may suggest less of a difference in the effects of bank mergers on borrowers of acquiring vs. target banks. On the other hand, the low number of bank lending relationships maintained by Belgian firms and the high proportion of firms with single lending relationships suggest that bank mergers might be expected to have stronger effects in Belgium than in countries where firms maintain many bank lending relationships.

Our main results can be summarized as follows. First, we find that bank mergers have short-run effects, in that firms borrowing from merging banks are significantly less likely to see their lending relationship terminated than otherwise similar borrowers. Longer-term effects, however, suggest that single relationship firms borrowing from one of the merging banks are more likely to lose their lending relationship, although overlap firms are still less likely to have the relationship terminated in the longer term. Second, when we differentiate between borrowers of target and acquiring banks, we find that borrowers at target banks are more likely to lose their relationship, whereas borrowers from acquiring banks are less likely to terminate their relationship

\footnotetext{
${ }^{3}$ Although we are not able to address this question directly, part of our ongoing work involves using data on changes in loan volumes to make some inferences about interest rates.
} 
following a merger. In addition, the differences between target and acquiring bank borrowers begin to appear immediately following the merger, and they become more robust in the longer run. These results are in accordance with what organizational theory would suggest and results reported in previous empirical research. One difference, however, is that our result relating to borrowers of acquiring banks appears to be stronger than findings reported elsewhere. A third result is that the effects of mergers differ for small and large firms and also vary for large firms borrowing from acquiring banks compared with large firms borrowing from target banks. Results also differ for target bank borrowers with single versus multiple lending relationships. Finally, overlap borrowers are less likely to lose their relationship with the consolidated bank than are firms borrowing from only one merging bank or firms borrowing from nonmerging banks.

The remainder of the paper is organized as follows. Section II reviews the literature and formulates hypotheses concerning the effects of bank mergers. Section III describes the banking environment and discusses sources of data. Section IV presents the results of regressions testing the impact of mergers. Section V concludes.

\section{Effects of bank mergers: literature review and hypotheses}

A growing literature investigates the impact of financial consolidation on lending to small and medium size firms. However, as argued in the introduction, only a few papers analyze the impact of bank mergers using individual bank-borrower data. In this section, we first develop a number of testable hypotheses concerning the impact of bank mergers on individual firm-bank lending relationships. To do this, we draw on theoretical and empirical literature, which provides predictions concerning the potential effects of mergers (see e.g. Berger, Miller, Petersen, Rajan and Stein, 2004; Farinha and Santos, 2002; or Sapienza, 2002). Afterwards, we review the literature on bank consolidation and small-business lending. In Section IV we test the hypotheses on Belgian bank mergers.

Are firms able to maintain or improve their bank relationships when banks consolidate? Which firms are more likely to be affected by bank mergers? How is borrower welfare modified after mergers? Are firms borrowing from several merging 
banks affected differently? The answers to these questions are related to the underlying forces for bank mergers themselves. Bank mergers should be initiated to maximize shareholder wealth, but often other forces related to agency problems may be at the origin of such mergers. Gains in shareholder value stem from two potential sources: efficiency and market power.

We start with a general discussion of the potential impacts of bank mergers in terms of efficiency and market power and conclude with a specific hypothesis concerning the impact of mergers on the termination rate of firm-bank relationships. Then, we elaborate on some modifications of this standard tradeoff between efficiency versus market power, and formulate a second hypothesis on the impact of financial consolidation on the rate of termination of firm-bank lending relationships that deals with different groups of firms.

\section{II.1 Efficiency versus market power}

A first impact of bank mergers is that they can lead to efficiency gains (for an overview on the impact of bank mergers, see Focarelli et al, 2002). Efficiency gains typically result from economies of scale, implying lower costs and/or higher revenues. These efficiency gains then are potentially passed on to customers. Examples of cost reductions are reductions in branch overlap, or savings on fixed costs. Efficiency gains leading to lower loan rates at the merging banks imply that borrowers are more likely to continue borrowing from the consolidated bank.

Mergers, however, also yield increased market power. The gains in market power hinge on the structure of banking markets, including characteristics like market concentration, barriers to entry related to informational incumbency advantages, informational gains of bank mergers, and other potential costs to firms in switching banks. Gains in market power allow consolidated banks to charge higher loan rates. Sapienza (2002) further develops these arguments by looking at different "types” of mergers. In particular, she argues that the efficiency and market power effects depend on the market overlap and the degree of competition among the merging banks prior to the consolidation. "In-market" mergers should allow a greater increase in market power and thus facilitate cooperation among banks (see Salant et al, 1983; Bernheim 
and Whinston, 1990; but for opposite predictions see Mester, 1987). At the same time, “in-market” mergers permit the realization of greater cost savings than "out-ofmarket” mergers. In sum, if the market power effect outweighs the efficiency effect, loan rates should increase or vice versa. Based on these insights, we formulate Hypothesis 1:

Hypothesis 1: When efficiency gains outweigh the effects of increased market power, firm-bank lending relationships are less likely to be terminated, and merging banks are more likely to attract new borrowers. Conversely, when market power outweighs efficiency gains, firm-bank relationships are more likely to be terminated, and consolidated banks are less likely to attract new borrowers.

II.2 Borrower heterogeneity: Modifications of the trade-off between efficiency versus market power

Are all firms equally affected by bank mergers? Which borrowers are likely to gain and which borrowers are expected to lose from bank mergers? Karceski, Ongena and Smith (2004) review the heterogeneous impacts of bank mergers on borrower welfare, highlighting modifications to the previously discussed trade-off between efficiency and market power.

A first distinction is related to differences between borrowers at acquiring versus target banks. Do firms borrowing from acquiring banks exhibit different rates of termination of lending relationships than firms borrowing from target banks? First, borrowers of target banks will be harmed when the target bank was previously granting below-cost loans. Merger-related increases in loan rates and loan denials then can be expected at the target bank. Second, borrowers at target banks are hurt more than borrowers of acquiring banks when the merged bank adopts the strategic focus and the organizational structure of the acquiring bank (Peek and Rosengren, 1996; Houston et al, 2001). The reasoning is that the adoption of the "rules" of the acquiring bank makes the target bank's borrowers less likely to be in conformance with the new rules. Moreover, soft information available at the target bank may be lost when key employees are more likely to leave the merged bank or move within the new organization. In sum, we may expect that target bank borrowers are more likely to 
have their lending relationship terminated at the consolidated bank than are acquiring bank borrowers.

Are large borrowers differently affected than small borrowers by a bank merger? This question is related to the issue of the "size effect of lending". Stein (2002) argues that the hierarchical structure of banks produces a size effect of lending. Larger banks and branches are more complex financial institutions and may have a different organizational structure than small banks. Large banks concentrate on larger firms, and reduce the amount of lending to small businesses (see also Strahan and Weston, 1998, and Peek and Rosengren, 1996). This may be driven by the fact that: (1) servicing large versus small firms is entirely different (transactional lending versus relationship lending; also see Petersen and Rajan (1994, 1995)); or (2) small banks have a better technology for servicing small firms (see also Cole et al, 2004, and Udell, 1989). This implies that if larger banks reduce the supply of credit to small borrowers, small borrowers may be more likely to lose their relationships. Alternatively, it is possible that small banks are intrinsically less efficient. In this case a merged bank becomes larger and better able to service small firms, which would imply that smaller borrowers would not face a higher probability of having their relationship with the bank terminated.

Some theories also point to demand side effects. A heterogeneous impact may be related to the magnitude of "borrower switching costs". These switching costs determine whether it is advantageous for firms to switch banks, or whether they are locked-in. In the event of switching, borrowers face "informational” switching costs and "transactional" switching costs (see e.g. Bouckaert and Degryse, 2004; Degryse and Ongena, 2004; or Kim et al, 2003; Klemperer (1995) provides a review of switching costs). ${ }^{4}$ These costs may be heterogeneous across firms. Whereas firms with low switching costs could leave the merged bank if interest rates rise as a result of the merger or if other banks start to actively poach borrowers from merged banks, firms with high switching costs will typically continue with the consolidated bank.

\footnotetext{
4 "Informational" switching costs stem from the fact that an inside bank possesses an informational advantage vis-à-vis outside banks. Firms willing to switch banks might be perceived of lower quality and therefore pay a higher loan rate. "Transactional” switching costs refer to higher costs that are incurred in visiting another bank. Examples of the latter are differences in geographical convenience, paperwork, different standards at banks etc.
} 
Thus, whether or not borrower welfare is harmed when the lending relationship is dropped after a merger hinges on the magnitude of switching costs and whether firms can find financing alternatives. Informational switching costs are positively related to the degree of "informational opacity". We can expect that larger firms, more profitable firms and firms having more tangible assets have fewer problems in credibly communicating their value to other financiers. Switching costs may also be expected to be lower for firms with multiple lending relationships rather than single relationships.

Finally, are firms borrowing from two merging banks treated differently from firms borrowing from only one merging bank? A bank merger decreases the number of firm-bank relationships mechanically for firms borrowing from at least two of the merging banks. If firms have previously chosen an optimal number of relationships, then firms being hit by this "drop in number of relationships" face incentives to increase this number again. Most likely this implies that firms will be less inclined to drop their relationship at the consolidated bank. ${ }^{5}$ This force would not be present for firms borrowing from only one of the merging banks. ${ }^{6}$

Mergers may improve information about borrowers. Informational effects of mergers are thus another important force for differences between firms borrowing from one versus several of the merging banks. Panetta et al. (2004) argue that when considering firms borrowing from several merging banks, the consolidated bank should be able to better tailor interest rates to the firm's riskiness. The reasoning is that consolidation improves bank's informational abilities in discriminating among low- and high quality borrowers. How does this "information pooling” between merging banks impact the probability of severing a relationship? The pooling of information provides the consolidated bank with a more precise signal about firms borrowing from both merging banks. This augments the consolidated bank's information advantage vis-àvis outside banks. It allows banks to stop lending to non-creditworthy borrowers and to continue lending to its most creditworthy borrowers.

\footnotetext{
${ }^{5}$ Admittedly, in a world without frictions, firms could simply choose to substitute the two merging banks with two other banks.

${ }^{6}$ Also the consolidated bank has incentives to revisit the position of the firms. For example, it may force out very large firms as the entire exposure to the firm may exceed certain limits. As our focus is on SMEs, we expect that this argument is not at play.
} 
On the other hand, based on informational hold-up arguments, outside banks bidding for borrowers having loans with two of the merging banks now face an increased winner's-curse effect yielding the consolidated bank additional market power (see e.g. Hauswald and Marquez, 2003; or von Thadden, 2004), which could lead to a decreased interest rate sensitivity to firm's risk characteristics. This informational gain is only present for overlap borrowers and not for firms borrowing from only one of the merging banks. The Belgian context with few bank relationships allows for a clear identification of these informational gains.

The above arguments suggest that the different potential forces do not all point in the same direction. We nevertheless conjecture that overlap borrowers are less likely to have the lending relationship at the consolidated bank terminated than firms borrowing from only one of the merging banks.

We can summarize the above discussion by the following hypothesis.

Hypothesis 2: Bank mergers produce heterogeneous effects on lending relationships of firms with different characteristics. Relationships are more likely to be terminated:

a) at target banks than at acquiring banks,

b) for small firms than for large firms,

c) by firms with lower switching costs than by other firms

d) for firms borrowing from only one, rather than overlap borrowers.

\section{II.3. Results from previous empirical studies}

There is a growing empirical literature dealing with the effects of bank mergers on borrowers. Due to lack of detailed micro-data, however, most studies rely on aggregate bank balance sheet data to infer the impact of bank mergers. The main findings of this approach are that merged banks seem to turn more towards larger 
borrowers and drop small borrowers. However, other external providers of finance seem to "fill the gap" over time by offering loans to small firms. ${ }^{7}$

As we have already noted, only a few studies examine the impact of bank mergers on individual borrowers using firm-level data. One important source of data for these studies has come from the Italian credit register. Sapienza (2002) uses this data source to study the effects of Italian bank mergers borrowers' credit lines. ${ }^{8}$ In particular, Sapienza investigates how borrowers' loan rates evolve after bank mergers, and also whether mergers induce termination of lending relationships. She finds that loan rates decrease after bank mergers, suggesting evidence for an efficiency effect of mergers. However, this efficiency effect is offset by a market power effect: loan rates increase following mergers when the market share of the acquiring bank is substantial. With respect to the effects of mergers on the termination of lending relationships, Sapienza finds that mergers raise the probability of termination but that target banks in mergers are more likely to terminate lending relationships than are acquiring banks. Indeed, the effects of mergers on the termination rates of lending relationships for borrowers of acquiring banks appear to be very small. Also, the effect of target banks' higher termination rates is stronger for small target banks than for large target banks. Finally, small borrowers tend to be more strongly affected by the increased probability of termination due to mergers than are larger borrowers. ${ }^{9}$

Chionsoni, Foglia and Marullo-Reedtz (2004) also rely on the Italian credit register to study bank mergers and find that borrowers that are kept on at merged banks have a lower probability of default than other borrowers in the population. Panetta, Schivardi and Shum (2004) deal with loan pricing after Italian bank mergers. They argue that bank mergers should improve the consolidated bank's informational abilities to discriminate between low- and high-quality borrowers. These gains may come from an improvement in the bank's ability to process an information set, or through pooling of information for firms borrowing at several merging banks. These authors indeed find that after a merger, the relation between the default probability of a firm and its

\footnotetext{
${ }^{7}$ Examples are Berger and Udell (1996), Peek and Rosengren (1996), and Strahan and Weston (1998). A review is provided in Berger, Demsetz and Strahan (1999).

${ }^{8}$ Sapienza chooses credit lines because these are nonsecured lines, which enables her to compare interest rates across borrowers without having to take into account collateral.
} 
loan rate becomes steeper, suggesting that mergers do improve information. Moreover, they also find that the informational gains are not driven by the explicit pooling of information about the same firm between the merging banks, as the increase in the slope of the link between risk and interest rates is the same for firms borrowing from one merging bank only and for those that were borrowing from both of the merging banks.

A final paper dealing with bank mergers and relationship termination is that of Karceski, Ongena and Smith (2004), which uses data on publicly listed Norwegian companies. They estimate the impact of bank mergers on borrower's stock prices and link bank mergers to termination rates of relationships. They find that smaller borrowers of target banks are hurt. Overall, this suggests that the welfare of borrowers may be influenced by a strategic focus that favors acquiring borrowers. They also find that bank mergers increase the relationship termination rates of borrowers at target banks but not at acquiring banks. ${ }^{10}$

\section{Banking environment and description of data}

In this section we describe the Belgian banking environment, the number of bank lending relationships maintained by Belgian SMEs, and the data sources for our analysis. We first document the increase in banking sector concentration arising from bank mergers and the importance of large banks in lending to small firms in Belgium. We then point to the low number of bank lending relationships maintained by Belgian SMEs and a decline in the number of lending relationships over time. Finally, we discuss the sources of data used in our empirical analysis and provide summary statistics for the firms and banks in our sample.

\section{III.1 Banking environment and bank-firm lending relationships}

Concentration in the Belgian banking sector has steadily increased over the past decade and is currently quite high. A small number of large banks now accounts for a high percentage of banking sector assets, deposits, and loans. Indeed, every large bank

\footnotetext{
${ }^{9}$ Note, however, that termination of a lending relationship in this context represents the more narrow concept of a drop of a credit line.
} 
currently operating in the Belgian banking sector has been involved in some type of merger or acquisition in the past ten years.

The graph below depicts Herfindahl indices over time for assets, deposits, and loans in the Belgian banking sector and illustrates the increase in concentration that has occurred in each of these areas. The increases in these indices between 1997 and 2002 reflect effects of the mergers that we analyse in this paper. Banks accounting for roughly 58 percent of banking sector assets in 1997 were involved in mergers between 1997 and 2002. ${ }^{11}$

\section{Chart 1. Herfindahl Index for Belgian banking sector}

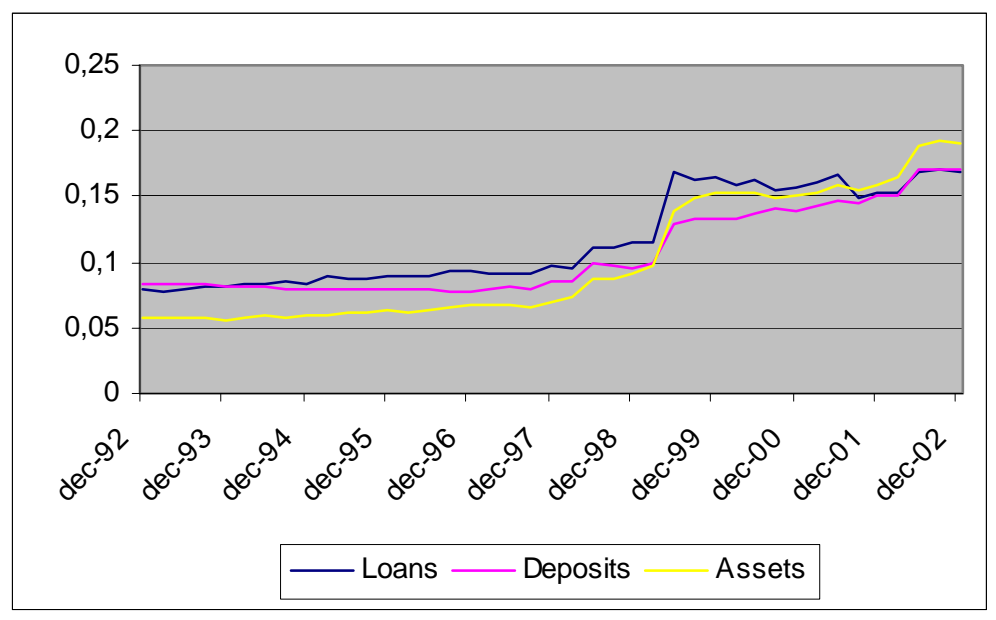

Source: Bank balance sheet data

Table 1 shows the time variation in the four-bank concentration ratios of loans to firms reported in the credit register. The market shares are reported for all firms taken together, as well for different size categories, as defined in the Basel II accord (corporates, corporate SMEs and retail SMEs). ${ }^{12}$ This table reveals that the share of

\footnotetext{
${ }^{10}$ Scott and Dunkelberg (2003) investigate for the US, using the 1995 National Federation of Independent Business data, the effect of bank mergers on a firm's attempt to obtaining financing. They find that the incidence of a merger raises the frequency of searching for a new bank.

${ }^{11}$ Our empirical analysis focuses on the three major banking mergers that occurred during this period. Although there were thirteen other banking mergers among small banks where at least one of the banks involved reported a credit to the credit register, all of these mergers involved only a few firms. In particular, the maximum number of borrowers in any of these mergers was 362, whereas the average number of borrowers involved was 124 .

${ }^{12}$ Corporates are defined in the Basel II accord as firms with greater than 50 million Euro in annual sales; SMEs have sales below 50 million Euro. (Subject to national discretion, the Basel Committee allows substituting the value of assets for sales when the latter is unavailable.) In addition, retail SMEs
} 
large banks in loans to firms has increased for all size categories, including the smallest firms. The market share of the four largest banks in loans to small and medium size firms is now very high.

Table 1: Four-bank concentration ratios in loans to firms by Basel II firm size category

(Percentages)

\begin{tabular}{|lcccccc|}
\multicolumn{1}{l}{} & Dec-97 & Dec-98 & Dec-99 & Dec-00 & Dec-01 & Dec-02 \\
\hline All firms & 58,0 & 66,4 & 78,5 & 77,2 & 79,0 & 83,5 \\
\hline Corporate & 49,9 & 55,4 & 68,00 & 71,3 & 69,3 & 81,5 \\
Corporate & & & & & & \\
SME & 54,4 & 64,3 & 79,5 & 76,2 & 80,5 & 85,2 \\
Retail SME & 71,4 & 78,3 & 84,9 & 84,2 & 84,3 & 86,7 \\
\hline
\end{tabular}

Source: Credit register.

As a point of comparison, Cetorelli and Gambera (2001) report the average threebank concentration ratios based on total assets in different countries over the period 1989-1996. They find that the three largest banks account for 49 percent in Belgium, 15 percent in the US, 24 percent in Italy, 27 percent in Germany, and 50 percent in the United Kingdom. Of course, in countries like the US or Italy, banks concentrate their activities in specific geographic areas, implying that some local markets are also highly concentrated in these countries. ${ }^{13}$ Nevertheless, the evidence by Cetorelli and Gambera (2001) illustrates that the Belgian market was already quite concentrated before the starting date of our sample.

Table 2 presents summary statistics on the number of bank lending relationships maintained by Belgian firms in 1997 and in 2003, again broken down by Basel II size category. From this table we observe that the average number of bank lending relationships for all firms taken together is low, although the number of lending relationships increases with firm size. ${ }^{14}$ The average number of bank lending relationships for firms in each size category has declined over time. ${ }^{15}$

are those SMEs for which the total exposure of any single banking group to the firm is less than 1 million Euro.

${ }^{13}$ Sapienza (2002) reports that in 1994, 49 Italian provinces had a Herfindahl-Hirschman Index (HHII) in between 0.10 and 0.18 , and 29 provinces had an HHI greater than 0.18 .

${ }^{14}$ A relationship is defined when firms are "currently" lending from a bank. This relationship measure may be narrower than the ones used in other studies looking at the number of relationships in Belgium, where also "past" lending or other services may be taken into account (see e.g. Ongena and Smith (2000), or de Bodt, Lobez and Statnik (2002)). However, Belgium seems not an exception in having a low number of bank relationships. 
Table 2 Numbers of firms and numbers of bank relationships by Basel size category

\begin{tabular}{|l|r|r|r|r|r|r|}
\hline & $\mathbf{N}$ & Mean & Median & Min & Max & $\begin{array}{r}\text { Std. } \\
\text { dev. }\end{array}$ \\
\hline $\mathbf{1 9 9 7}$ & & & & & & \\
\hline Total & 100432 & 1,30 & 1 & 1 & 16 & 0,70 \\
\hline Corporate & 904 & 3,31 & 3 & 1 & 15 & 2,44 \\
\hline Corporate SME & 5397 & 2,02 & 2 & 1 & 16 & 1,29 \\
\hline Retail SME & 94131 & 1,24 & 1 & 1 & 7 & 0,54 \\
\hline & & & & & & \\
\hline $\mathbf{2 0 0 3}$ & & & & & & \\
\hline Total & 122904 & 1,21 & 1 & 1 & 9 & 0,53 \\
\hline Corporate & 997 & 2,30 & 2 & 1 & 9 & 1,42 \\
\hline Corporate SME & 6011 & 1,72 & 1 & 1 & 9 & 0,95 \\
\hline Retail SME & 115896 & 1,17 & 1 & 1 & 5 & 0,45 \\
\hline
\end{tabular}

Source: Credit register

\section{III.2 Data sources and summary statistics}

We rely on three sources of data for our analysis:

(1) Data from the credit register, which contains information on loans to Belgian firms granted by banks operating in Belgium. Our data cover the period 19972003 and contain both authorised and utilised volumes by type of loan by bank. The banks represented in the data include all foreign and domestic banks operating in Belgium which either authorised or had outstanding loans during the period to non-financial firms. Loans to Belgian firms that were extended by foreign banks or branches outside of Belgium are not included in the data set. Also, the credit register contains no data on interest rates or collateral.

(2) Firm balance sheets. These data come from firms' annual balance sheet filings during the period 1994-2002. Small and medium-size firms in Belgium are allowed to file a short balance sheet form, which is less complete than the long

For example, results for France indicate that about $60 \%$ of firms having sales of less than $€ 2.5$ million have one bank lending relationship (Dietsch and Golitin-Boubakari, 2002, credit register data for 2000). In Portugal, about 57\% of the firms has a unique relationship (Farinha and Santos, 2000, credit register data for 1995).

\footnotetext{
${ }^{15}$ Although we present data for only the first and last years of our period, data for the intermediate years confirm a steady decline in the average number of lending relationships across all size categories of firms. For example, the average number of lending relationships for all firms in each of the years 1998-2002, respectively, are: 1,28; 1,26; 1,25; 1,23; 1,22. In previous work (see Degryse et al, 2004), we have investigated the determinants of the number of firm-bank relationships for the years 1997 and
} 
form required for large firms. Hence, certain data such as sales and number of employees (for which reporting is voluntary on the short form) are not available for all firms. As a result, we rely on the book value of assets as a measure of firm size, rather than number of employees or sales.

(3) Bank balance sheets. These contain annual balance sheet data, which banks are required to report under the Supervisory Reporting Scheme (Schema A). These data are available from 1992-2003

While the credit register data offer a unique source of information relating to firms' bank lending relationships and loan volumes, the limitations of these data suggest some restrictions and caveats for our analysis. Most importantly, because the credit register data include only banks operating on Belgian territory and thus exclude foreign banks operating outside of Belgium, it is possible that the number of bank relationships for large firms is understated in these data. If large Belgian firms borrow from foreign banks that are not located in Belgium, then those relationships will not be captured in the data. This suggests restricting our attention to small and mediumsize firms.

In all of the analysis that follows, we have excluded all firms that meet the Basel II classification as "corporate" (i.e., with sales exceeding 50 million $€$ ), as well as all firms with assets exceeding 500 million $€^{16}$

The credit register data include information on authorised loan volumes and on actual borrowing (utilised loan volumes). We rely on utilised volumes for our analysis, on the assumption that bank lending relationships are more likely to be valuable to firms to the extent that lending actually occurs.

We construct a panel consisting of observations of firm-bank lending relationships in December of each of the years 1997-2003. The firms included in the panel are those

2002. The determinants were quite stable over time, suggesting that other structural changes in the financial sector may explain the drop in the number of relationships over time.

${ }^{16}$ The Belgian economy has a large number of coordination centers. These are generally subsidiaries of international firms that have been established in Belgium to benefit from tax advantages. They carry out activities for other group entities such as centralization of accounting, administration, and financial transactions. Because coordination centers do not behave like typical firms, they have also been excluded from our regression analysis. 
SMEs that had at least one bank lending relationship in December, 1997. These firms are included for every year of the panel (unless the relation is terminated, in which case the observation disappears). Because we are interested in observing the effects of mergers on firms that were borrowing from merging banks prior to the merger, we exclude from the panel all firms that entered into the credit register after December, 1997.

Table 3 presents summary statistics for the firms and the banks in our panel.

Table 3. Panel summary statistics: firm and bank characteristics

Summary statistics for firms are based upon all firm-year observations included in the panel data analysis, which consists of yearly observations from Dec., 1997-Dec., 2003. Bank summary statistics are based upon all bank-year observations included in the panel. Firm and bank asset values are in thousands of $€$ (2002 values). All variables definitions are provided in the Appendix.

\begin{tabular}{|lcccc|}
\hline & N & Mean & Median & Std. Dev. \\
Firm & & & & \\
characteristics & & & & \\
AGE & 472.109 & 11,65 & 11,96 & 10,27 \\
ASSETF & 472.109 & 1752 & 498 & 8954 \\
ROAF $(*)$ & 472.109 & $5,97 \%$ & $5,37 \%$ & $10,86 \%$ \\
LEVERAGE $(* *)$ & 472.109 & $75,12 \%$ & $74,85 \%$ & $38,67 \%$ \\
& & & & \\
Bank & & & & \\
characteristics & & & & \\
ASSETB & 500 & 8808294 & 810957 & 30219522 \\
ROAB & 500 & $0,16 \%$ & $0,25 \%$ & $1,51 \%$ \\
BADLOANSB & 500 & $1,95 \%$ & $0,92 \%$ & $3,21 \%$ \\
OPCOSTB & 500 & $8,77 \%$ & $6,66 \%$ & $6,78 \%$ \\
LIQB & 500 & $10,83 \%$ & $13,05 \%$ & $39,07 \%$
\end{tabular}

$(*)$ Firms with ROA $>99 \%$ and $<-99 \%$ are excluded.

$(* *)$ Firms with Debt/Equity $>1000 \%$ are excluded.

The median firm has an age of about 12 years; $498.000 €$ of total assets; a return on assets of about 5.4\%; and a leverage - defined as the book value of debt over assets of 75 percent. The bottom panel of Table 3 presents the bank-year characteristics for all banks in our sample

Table 4 reports summary statistics on firm characteristics for different groups of firmbank relationships: firms borrowing from an acquiring bank in a merger (but no other bank involved in the merger); firms borrowing from a target bank in a merger (but no other bank involved in the merger); firms borrowing from both the acquiring and a 
target bank in a merger (“overlap” borrowers); those borrowing from nonmerging banks. This table indicates few differences in the characteristics across groups. Firms borrowing from target banks are slightly younger than other firms. Also, overlap borrowers are older and larger than other firms; however, their profitability (ROAF) and leverage (LEVERAGE) are similar to the values for firms in other groups.

\section{Table 4 Summary statistics for acquiring and target bank borrowers}

Summary statistics for firms are based upon all firm-year observations included in the panel data analysis, which consists of yearly observations from Dec., 1997-Dec., 2003. Assets are in thousands of $€$ (2002 values). All variables definitions are provided in the Appendix.

\begin{tabular}{|c|c|c|c|}
\hline & Mean & Median & Std. Dev. \\
\hline \multicolumn{4}{|c|}{ Firms borrowing from acquiring bank } \\
\hline AGE & 10,59 & 10,56 & 10,11 \\
\hline ASSETF & 1588 & 504 & 7825 \\
\hline ROAF (*) & $5,75 \%$ & $5,26 \%$ & $10,80 \%$ \\
\hline LEVERAGE $(* *)$ & $75,03 \%$ & $75,21 \%$ & $37,40 \%$ \\
\hline \multicolumn{4}{|c|}{ Firms borrowing from target bank } \\
\hline AGE & 8,40 & 9,00 & 9,35 \\
\hline ASSETF & 1638 & 339 & 10006 \\
\hline ROAF (*) & $5,79 \%$ & $5,46 \%$ & $11,51 \%$ \\
\hline LEVERAGE $(* *)$ & $78,13 \%$ & $77,59 \%$ & $41,28 \%$ \\
\hline \multicolumn{4}{|c|}{$\begin{array}{l}\text { Overlap firms (borrowing from both target and acquiring } \\
\text { banks) }\end{array}$} \\
\hline AGE & 14,36 & 13,98 & 13,81 \\
\hline ASSETF & 6691 & 1347 & 21523 \\
\hline $\operatorname{ROAF}(*)$ & $6,10 \%$ & $5,21 \%$ & $8,27 \%$ \\
\hline LEVERAGE $(* *)$ & $72,80 \%$ & $74,78 \%$ & $24,12 \%$ \\
\hline \multicolumn{4}{|c|}{ Firms borrowing from nonmerging banks } \\
\hline AGE & 11,86 & 11,90 & 10,27 \\
\hline ASSETF & 1758 & 500 & 8954 \\
\hline $\operatorname{ROAF}(*)$ & $6,01 \%$ & $5,37 \%$ & $10,85 \%$ \\
\hline $\operatorname{LEVERAGE}(* *)$ & $75,04 \%$ & $74,70 \%$ & $38,77 \%$ \\
\hline
\end{tabular}

$(*)$ Firms with ROA $>99 \%$ and $<-99 \%$ are excluded.

$(* *)$ Firms with Debt/Equity $>1000 \%$ are excluded.

Table 5 reports bank characteristics for the acquiring and target banks at the time of the merger. We observe that acquiring and target banks are similar to other banks in the sample except for size: acquiring and target banks are on average larger than other banks in the sample. 
Table 5 Summary statistics for acquiring and target banks

Acquiring and target bank statistics are at the time of the merger. Assets are in thousands of $€$ (2002 values). All variables definitions are provided in the Appendix.

\begin{tabular}{|c|c|c|}
\hline & Mean & Std. Dev. \\
\hline \multicolumn{3}{|c|}{ Acquiring bank characteristics } \\
\hline ASSETB & 95670164 & 188000 \\
\hline ROAB & $0,27 \%$ & $0,14 \%$ \\
\hline BADLOANSB & $1,29 \%$ & $1,06 \%$ \\
\hline OPCOSTB & $9,28 \%$ & $7,52 \%$ \\
\hline LIQB & $15,11 \%$ & $3,52 \%$ \\
\hline \multicolumn{3}{|c|}{ Target bank characteristics } \\
\hline ASSETB & 34037556 & 216000 \\
\hline ROAB & $0,29 \%$ & $0,22 \%$ \\
\hline BADLOANSB & $1,33 \%$ & $1,15 \%$ \\
\hline OPCOSTB & $9,19 \%$ & $5,69 \%$ \\
\hline LIQB & $17,66 \%$ & $16,99 \%$ \\
\hline
\end{tabular}

\section{Empirical Analysis for Belgium}

In this section we test the hypotheses developed in Section II. The general question motivating our analysis is whether firms borrowing from merging banks are affected by the merger. In essence, this question asks not only whether borrowers of merging banks are treated differently from borrowers of banks not involved in mergers but also whether borrowers of merging banks are treated differently by the merged bank than they were by the individual (merging) banks prior to the merger. Investigation of several specific questions helps to provide a complete picture. Do borrowers of merging banks face a higher probability of losing their lending relationships than borrowers of non-merging banks? How are any merger-related effects spread out over time? Are dissimilar borrowers affected differently; e.g. borrowers of target vs. acquiring banks, overlap borrowers, borrowers of different sizes, borrowers with single versus multiple lending relationships prior to the merger.

As described in Section II, banks accounting for $58 \%$ of assets in the Belgian banking sector have been involved in "in-market" mergers between 1997 and 2002. We focus our analysis on the three major bank mergers that occurred during this period, as these mergers are covered by the 1997-2003 panel for which we have data from the credit 
register. Each of these mergers involved at least two large banks. ${ }^{17}$ We take the date of the merger as that on which the banks involved began providing unified credit statistics to the credit register, which is the date of the legal merger. Our classification of whether a bank is an acquirer or target is based on the classification provided by the Belgian banking and finance commission (CBFA) in their annual reports.

We present two complementary empirical approaches for investigating merger effects. First, we perform a panel regression analysis, which allows us to identify "combined” effects of the mergers, to control for time effects, to control for merging bank behavior prior to the merger, and to differentiate short-term versus longer-term merger effects. Second, as a robustness check and to identify any heterogeneity across mergers, we run regressions for each merger individually.

\section{IV.1 Panel regression specification}

Our basic regression specification is a logit-regression, where the dependent variable DROPPED is a dummy variable which takes the value 1 if the firm loses its relationship with the bank during the twelve-month period following the time of the observation.

We estimate the following logit specification:

$\ln \left[\frac{p\left(D R O P P E D_{i k t}=1\right)}{1-p\left(D R O P P E D_{i k t}=1\right)}\right]=\alpha_{0}+\alpha_{1} M E R G 1_{k t}+\alpha_{2} M E R G 2_{k t}+\alpha_{3} M E R G 1_{k t-1}+\alpha_{4} M E R G 2_{k t-1}$

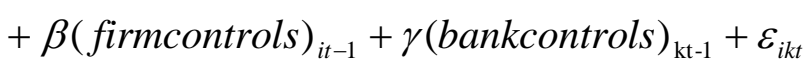

where each observation represents a firm-bank relation and where $D R O P P E D_{i k t}$ equals one if during the twelve months following time $t$ firm $i$ lost its relationship with bank $k$. The variables $M E R G 1_{k t}$ and $M E R G 2_{k t}$ are dummy variables that allow us to identify firms that were borrowing from banks involved in a merger. $M E R G 1_{k t}$ is a dummy variable which equals one if bank $k$ was involved in a merger in the twelve months following time $t$ and if firm $i$ was not borrowing from any of the other banks involved in the merger. $M E R G 2_{k t}$ is a dummy variable equal to one if bank $k$ was

\footnotetext{
${ }^{17}$ Thirteen other mergers of smaller banks also occurred during this period; however, these mergers involved banks with only a very small number of firms in our sample (see footnote 12 for details).
} 
involved in a merger in the twelve months following time $t$ and firm $i$ was an overlap borrower. That is the firm was borrowing from, in addition to bank $k$, at least one of the other banks involved in the merger. These two variables allow us to distinguish the effects of mergers for firms borrowing from only one of the merging banks versus overlap firms.

Because each of the three mergers covered by our panel occurred roughly in the middle of a year, using observations in December in each year for the panel allows us to measure the "short term" merger effects as those occurring in a twelve-month period around the merger, including six months following the merger. That is, if a merger occurred in June, 1998, the value of $M E R G 1_{k t}$ (together with DROPPED) for $t=$ December, 1997 indicates whether the firm borrowing from one bank involved in the merger lost its relationship or not with the merged bank in the six months following the merger.

To investigate "longer-term" effects of mergers, we introduce the dummy variables $M E R G 1_{k t-1}$ and $M E R G 2_{k t-1}$, which are defined similarly to the short run merger variables but which equal one when firm $i$ was borrowing from one or two merging banks at time $t-1$ (and when the merger occurred between time $t-1$ and $t$ ), respectively. ${ }^{18}$ These dummy variables capture the effects of mergers during the period of six months to eighteen months following the merger, which we from now on call longer-term effects. ${ }^{19}$

We include firm and bank control variables in the logit regression, as well as industry and year dummies. As firm controls we include measures of firm age, size, profitability, leverage, and year of most recent filing of balance sheet. The motivation for the particular firm control variables comes from previous merger literature and the literature on the determinants of number of relationships (see e.g. Farinha and Santos, 2002; Detragiache et al, 2000; Ongena and Smith, 2000), as well as our own estimates with Belgian data (see Degryse et al, 2004). Older, larger and more profitable firms

\footnotetext{
${ }^{18}$ For the example of the June, 1998 merger the variable MERG1 $1_{\mathrm{kt}-1}$ would equal one for the observation $t=$ Dec., 1998 for firms that had been borrowing from the merging bank in Dec., 1997.

${ }^{19}$ The short duration of our panel, combined with the large proportion of banking assets involved in mergers, prevents us from estimating the effects of mergers over a longer period following the merger.
} 
may have lower switching costs in that more public information is available about them. Leverage is introduced to control for certain demand factors. We expect that more levered firms are less likely to lose a lending relationship. However, firms that are too highly levered (e.g., financially distressed firms) may be more likely to lose a relationship. In the same spirit we introduce the year of most recent balance sheet filing. We suspect that halting the filing of balance sheets is one of the steps on the way to a firm's exit, either through bankruptcy or voluntary liquidation.

We also include bank control variables in our specification, the motivation for which comes from the fact that losing a firm-bank relationship may be related to bank specific characteristics. ${ }^{20}$ For example, Detragiache et al (2000) argue that bank liquidity is important for the continuation of firm-bank relationships. Berger et al (2004) find that large US banks tend to have shorter relationships. Bank controls include measures of size, profitability, cost efficiency, bad loans, and liquidity. All variable definitions are provided in the Appendix. Year and industry dummies are introduced to control for business cycle effects and industry effects, respectively.

The results of the regression for our basic specification are displayed in Table 6. We report regressions separately for different samples: all firms, firms with a single bank relationship, and firms with multiple bank relationships. ${ }^{21}$ The motivation for looking at the two subsamples - single relationships and multiple relationships - stems from potential differences in switching costs and availability of alternative sources of finance. Firms with multiple relationships may have more bargaining power with respect to the merged bank.

\footnotetext{
${ }^{20}$ To our knowledge, the motivations for the three mergers were not related to bank distress. Moreover, (unreported) summary statistics for the acquiring and target banks for variables reported in Table 4 are in line with the values for other banks in the sample, with the exception of size; the merging banks all have asset values greater than the 75th percentile value for all banks in the sample. ${ }^{21}$ The reader may notice that our sample splits (single relationships and multiple relationships) allow firms to move from one sample to another sample due to merger related effects. If a firm was borrowing from only two banks, both of which were involved in a merger, then the firm automatically has a single relationship after the merger (if its lending relationship is not severed). Our results however remain robust to using as alternative selection device having single or multiple relationships about six months before the merger.
} 


\section{Table 6: Panel regressions: impact of mergers on lending relationships}

The dependent variable in each regression equals one if during the following year firm i loses its relationship with bank k. The reported coefficients are logit estimates of a marginal change in the independent variable on the probability of losing the lending relationship. All regressions include a constant term, firm industry dummies, and year dummies (not reported). Definitions of the variables are provided in Section III. *, **, *** denotes significance at the 10, 5, and 1\%-level, respectively (based on heteroskedastic-robust standard errors).

\begin{tabular}{|c|c|c|c|c|c|c|}
\hline \multirow[t]{3}{*}{ PANEL } & \multicolumn{3}{|c|}{$\begin{array}{c}\text { A } \\
\text { Without merging bank fixed effects }\end{array}$} & \multicolumn{3}{|c|}{$\begin{array}{c}\text { B } \\
\text { With merging bank fixed effects }\end{array}$} \\
\hline & \multicolumn{3}{|c|}{ Sample } & \multicolumn{3}{|c|}{ Sample } \\
\hline & All & Single rel. & $\begin{array}{l}\text { Multiple } \\
\text { rels. }\end{array}$ & All & Single rel. & $\begin{array}{l}\text { Multiple } \\
\text { rels. }\end{array}$ \\
\hline \multicolumn{7}{|l|}{ Firm controls } \\
\hline $\ln (\mathrm{AGEF})$ & $-0,002^{\star \star *}$ & $0,003^{\star \star *}$ & $-0,009 * * *$ & $-0,002^{\star \star \star}$ & $0,002^{\star \star *}$ & $-0,009^{\star * \star}$ \\
\hline $\ln (\mathrm{ASSETF})$ & $-0,020^{\star \star \star}$ & $-0,028^{\star \star \star}$ & $-0,012^{\star \star \star}$ & $-0,021^{* \star *}$ & $-0,029 * \star \star$ & $-0,013^{\star * *}$ \\
\hline ROAF & $-0,080^{\star \star \star *}$ & $-0,076^{\star \star \star}$ & $-0,077^{\star \star \star}$ & $-0,080^{* * *}$ & $-0,076^{\star \star \star}$ & $-0,078^{\star \star *}$ \\
\hline LEVERAGE & $-0,060^{\star \star \star}$ & $-0,075^{\star \star \star}$ & $-0,031^{\text {** }}$ & $-0,060$ *** & $-0,075^{\star \star *}$ & $-0,031^{* \star *}$ \\
\hline LEVERAGE*NEGEQ & $0,056^{\star \star *}$ & $0,063^{\star \star \star}$ & $0,041^{* * *}$ & $0,056^{\star \star \star}$ & $0,063^{\star \star \star}$ & $0,040^{\star \star *}$ \\
\hline RECBALANCE & $-0,049$ *** & $-0,056^{* * *}$ & $-0,032^{\star \star \star}$ & $-0,049 * \star *$ & $-0,056^{\star * \star}$ & $-0,032^{\star \star *}$ \\
\hline YOUNG & $0,018^{\star * *}$ & $0,023^{\star * *}$ & 0,010 & $0,018^{* * *}$ & $0,022^{\star * *}$ & 0,010 \\
\hline \multicolumn{7}{|l|}{ Merger variables } \\
\hline MERG1t & $-0,007^{\star \star \star}$ & $-0,001$ & $-0,018^{\star \star \star}$ & $-0,003^{* * *}$ & $0,003^{*}$ & $-0,013^{* * *}$ \\
\hline MERG2t & $-0,109^{\star \star \star}$ & - & $-0,105^{\star \star \star}$ & $-0,105^{\star \star \star}$ & - & $-0,106^{* * *}$ \\
\hline MERG1t-1 & $0,003^{*}$ & $0,005^{* *}$ & $-0,004$ & $-0,009^{\star}$ & $0,011^{* * *}$ & 0,000 \\
\hline MERG2t-1 & $-0,082^{\star \star \star}$ & - & 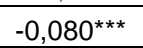 & $-0,079 * * *$ & - & $-0,107 * * *$ \\
\hline \multicolumn{7}{|l|}{ Bank controls } \\
\hline $\ln ($ ASSETB $)$ & $-0,021^{\star \star \star}$ & $-0,015^{\star \star \star}$ & $-0,027^{\star \star \star}$ & $-0,020^{* * *}$ & $-0,015^{\star \star \star}$ & $-0,025^{\star \star \star}$ \\
\hline ROAB & $0,642^{\text {*** }}$ & $1,137^{\text {*** }}$ & $0,422^{\star *}$ & $0,404^{\star \star \star}$ & $0,673^{\star \star * *}$ & $0,415^{\star \star}$ \\
\hline BADLOANSB & $0,922^{\star * *}$ & $1,278^{\star * *}$ & $0,624^{* * *}$ & $0,730^{* * *}$ & $0,555^{\text {*** }}$ & $0,786^{\star \star *}$ \\
\hline OPCOSTB & $0,254^{\star \star *}$ & $0,287^{\text {*** }}$ & $0,207^{\star \star}$ & $0,242^{* \star *}$ & $0,312^{\star * *}$ & $0,154^{\star * *}$ \\
\hline LIQB & $-0,028^{\star \star \star}$ & $0,003^{* \star}$ & $-0,034 * * *$ & $-0,027^{* \star *}$ & 0,012 & $-0,038^{\star \star \star}$ \\
\hline $\begin{array}{l}\text { Merging Bank } \\
\text { dummies }\end{array}$ & No & No & No & Yes & Yes & Yes \\
\hline \multicolumn{7}{|l|}{ Other variables } \\
\hline Single rel dummy & $-0,038^{\star \star \star}$ & - & - & $-0,038^{\star \star \star}$ & - & -- \\
\hline DROPPED = 1 & 77026 & 44669 & 32357 & 77026 & 44669 & 32357 \\
\hline DROPPED $=0$ & 534485 & 318655 & 215830 & 534485 & 318655 & 215830 \\
\hline Pseudo $\mathrm{R}^{2}$ & $5,11 \%$ & $5,27 \%$ & $6,05 \%$ & $5,13 \%$ & $5,49 \%$ & $6,31 \%$ \\
\hline Chi-Square & 0,0001 & 0,0001 & 0,0001 & 0,0001 & 0,0001 & 0,0001 \\
\hline
\end{tabular}

Panel A of Table 6 presents the results controlling for bank characteristics, but excluding merging bank fixed effects. Panel B includes merging bank fixed effects in addition to bank characteristics. ${ }^{22}$ Results are broadly consistent across these two

\footnotetext{
${ }^{22}$ Each of these specifications involves some bias. The regression without merging bank fixed effects does not control directly for a change in behavior of the merging banks pre and post-merger. On the other hand, the regression with merging bank fixed effects can only control for the fixed effects for two of the three mergers, as one of the mergers occurred too close to the beginning of our panel to allow us to control for the pre-merger behavior of the merging banks.
} 
specifications. All reported coefficients are the marginal effects computed on the basis of the regression coefficients. We discuss first the results for firm and bank control variables, then we turn to the merger variables.

The rate of termination of bank lending relationships in our sample is on average about 12.6 percent. $^{23}$ For comparison, the termination rate in Karceski et al (2004) is 6.9 percent and only 3 percent in Sapienza (2002). However, Chionsini et al (2004), who also use Italian data, report a termination rate of around 11 percent.

Firm controls. For convenience, we base our discussion on the "All" regression with merging bank fixed effects of Panel B, Table 6; however, results for the other regressions are similar. Where there are differences with respect to the other samples, we point them out. All of the firm control variables are statistically significant, and all of these variables are economically significant with the exception of firm age (ln(AGEF)), whose sign also differs for firms with single and multiple relationships. The probability of losing a lending relationship decreases with firm size (ASSETF), profitability (ROAF), and leverage (LEVERAGE). An increase in the log of firm assets by one standard deviation from its mean causes the probability of losing a lending relationship to decrease 2.9 percentage points below the average estimated probability in the sample of dropping a relationship of $12.6 \%$. This result contrasts with results obtained by Sapienza (2002) but is in line with Karceski et al. (2004). Our results thus indicate that smaller firms tend to have less stable relationships with their banks than do large firms.

As expected, higher firm profitability (ROAF) reduces the likelihood of termination of the lending relationship. An increase of ROAF by one standard deviation from its mean lowers the probability of dropping the relationship by 2.3 percentage points. However, firms that are too highly levered (those with negative equity) are more likely to lose their relationship. The marginal increase in the probability of losing a relationship for firms having a value of NEGEQ equal to one is 5.6\%. This implies that financially distressed firms have a higher probability of having their lending

\footnotetext{
${ }^{23}$ In line with this rate, Degryse and Van Cayseele (2000) report a mean duration of the lending relationship for Belgian firms of 7.87 years. This translates into a drop rate of 12.7 percent when assuming constant duration dependence.
} 
relationship terminated. Similarly, firms which have not yet filed a full-year balance sheet (YOUNG=1) and firms which have halted filing balance sheets $($ RECBALANCE $=0)$ are both more likely to lose their lending relationships. In sum, these results clearly indicate that firm variables are important in explaining termination of lending relationships.

Bank controls. All bank control variables are statistically significant in the regressions reported in Table 6. The coefficient on $\ln ($ ASSETB) indicates that lending relationships tend to have a lower drop rate for larger banks than for smaller banks. An increase of $\ln ($ ASSETB) by one standard deviation from its mean lowers the probability of dropping the relationship by 3.1 percentage points.

This result contrasts with the findings of Berger et al (2004), who report that in the U.S. larger banks tend to have shorter relationships with borrowers than do smaller banks. How can these different findings be reconciled? Berger et al (2004) interpret their findings as evidence of small banks being better able to handle soft information. Soft information binds a borrower to its bank over time and leads to longer relationships. Since large banks in our sample appear to have lower termination rates (and hence presumably longer lending relationships with firms), our evidence suggests that large banks in Belgium also appear able to deal with soft information. This is also consistent with our earlier observation that large Belgian banks are important in lending to SMEs. One possible explanation for this empirical result on bank size is that large Belgian banks maintain extensive branch networks, which allows for the gathering of soft information about small firms.

Bank return on assets (ROAB) in Table 6 appears with a (counterintuitive) positive coefficient; however, it does not appear to have a significant economic impact on the likelihood of termination of lending relationships. Bank liquidity (LIQB) appears in the different regressions with different signs and also is not economically significant. The remaining two bank characteristics, BADLOANSB and OPCOSTB, indicate that firms borrowing from banks having relatively higher proportions of non-performing loans over total loans and larger operating costs over total assets have larger termination rates. Our findings on BADLOANSB are consistent with the theory presented in Detragiache et al (2000) who argue that lending relationships are more 
likely to be terminated when borrowing from banks that are likely to be hit by a liquidity shock. Our results are also similar to those reported by Sapienza (2002). ${ }^{24}$

Merger variables. Table 6 suggests that mergers also have significant effects on the drop rate of lending relationships. The coefficients on the "short-run" effects MERG1t and MERG2t are generally negative and significant, although the result for MERG1t is slightly less consistent across regressions. So for example, in the "All" sample with merging bank fixed effects (Panel B), firms borrowing from only one merging bank have a probability of losing their relationship in the six months following the merger that is lower by $0.3 \%$ than for firms borrowing from nonmerging banks, and overlap borrowers have a probability that is $10.5 \%$ lower than nonmerging bank borrowers.

These results contrast with those obtained by other studies (e.g., Sapienza, 2002), where mergers do not appear to have significant effects in the short run. However, these results indicate that firms borrowing from banks involved in mergers (at least for the large mergers under consideration) were less likely than firms borrowing from nonmerging banks to lose their lending relationship. On the one hand, this result might suggest that the mergers under investigation were beneficial to firm borrowers (e.g., because efficiency effects of mergers dominated market power effects). On the other hand, this result is also consistent with the idea that the ultimate effects of mergers take time to be realized. The merged bank may decide to hold constant the lending policies of the merging banks for some period following the merger, before implementing the policy for the consolidated bank. For example, local branch managers may invest (even more) in the gathering of "soft" information, as branch closure decisions are not spelled out yet.

Support for the interpretation that merger effects are realized over time is given by the longer run merger effects (those occurring between six and eighteen months following the merger), which are reflected by the coefficients on MERG1t-1 and MERG2t-1. The coefficient on MERG1t-1 is positive and significant for firms with single lending relationships (the single relationship sample). The sign of the coefficient on MERG1t1 for the entire sample (“All”) depends on whether we control for merging bank fixed

\footnotetext{
${ }^{24}$ Detragiache et al (2000) use as empirical proxy the degree of bad loans and liquid assets. They find
} 
effects. On the other hand, the coefficient on MERG2t-1 is negative and significant for all regressions. These results again suggest that mergers have effects, but the effects may differ for borrowers that were borrowing from only one of the merging banks versus overlap borrowers (consistent with Hypothesis 2d). Firms with single relationships borrowing from only one of the merging banks appear more likely to lose their relationships following the merger; however, overlap firms are significantly less likely to lose their relationships than firms borrowing from nonmerging banks, and this effect is very strong.

As a point of comparison, Sapienza (2002) also finds significant merger effects; firms borrowing from merging banks have a probability of losing their relationship that is higher by $1.3 \%$ than for nonmerging bank borrowers. Most of this effect, however, seems to occur about four quarters after the merger. Sapienza does not distinguish between firms borrowing from only one versus two or more of the banks involved in a merger.

\section{IV.2 Target versus acquiring bank borrowers}

Given that merger effects appear to differ for firms borrowing from only one merging bank versus overlap borrowers, are the effects different for firms borrowing from the target and from the acquiring bank (Hypothesis 2a)? Table 7 reports the results of the regressions that address this question. We have replaced the merger variable MERG1t from the earlier regressions with two variables ACQUIREt and TARGETt, representing the short run merger effects for firms borrowing only from an acquirer bank or only from a target bank, respectively. Instead of the variable MERG2t, we now include the variable ACQTARGt, which represents firms that were borrowing from both the acquiring bank and at least one target bank. Similar variables, with $t-1$ subscripts, are defined to capture the longer run effects. Because the coefficients for the firm and bank controls are similar to those reported in Table 6, we report here and in all subsequent tables only the marginal effects for the merger variables.

that firms borrowing from "less liquid” banks maintain more firm-bank relationships. 
Table 7: Panel regressions: target versus acquirer banks

The dependent variable in each regression equals one if during the following year firm i loses its relationship with bank k. The reported coefficients are logit estimates of a marginal change in the independent variable on the probability of losing the lending relationship. All regressions include a constant term, firm industry dummies, and year dummies (not reported). Definitions of the variables are provided in Section III. *, **, *** denotes significance at the 10, 5, and 1\%-level, respectively (based on heteroskedastic-robust standard errors).

\begin{tabular}{|c|c|c|c|c|c|c|}
\hline \multirow[t]{3}{*}{ PANEL } & \multicolumn{3}{|c|}{$\begin{array}{c}\text { A } \\
\text { Without merging bank fixed effects } \\
\end{array}$} & \multicolumn{3}{|c|}{$\begin{array}{c}\text { B } \\
\text { With merging bank fixed effects }\end{array}$} \\
\hline & \multicolumn{3}{|c|}{$\begin{array}{c}\text { Sample } \\
\end{array}$} & \multicolumn{3}{|c|}{ Sample } \\
\hline & All & Single rel. & Multiple rels & All & Single rels. & Multiple rels \\
\hline ACQUIREt & $-0,016^{\star \star \star}$ & $-0,007^{\star \star \star}$ & $-0,030 * \star \star$ & $-0,011^{\star \star \star}$ & $-0,005^{\star \star}$ & $-0,022^{\star * \star}$ \\
\hline TARGETt & $0,016^{* \star *}$ & $0,018^{* \star *}$ & $0,020^{* * *}$ & $0,015^{\star \star \star}$ & $0,023^{\star \star *}$ & 0,007 \\
\hline ACQTARGt & $-0,104^{\star \star *}$ & & $-0,109^{* \star \star}$ & $-0,103^{\text {** }}$ & - & $-0,106^{\star \star \star}$ \\
\hline ACQUIREt-1 & $-0,026^{\star \star *}$ & $-0,024^{* \star *}$ & $-0,032^{* * \star}$ & $-0,021^{\star \star \star}$ & $-0,020$ *** & $-0,024^{* \star \star}$ \\
\hline TARGETt-1 & $0,071^{* \star *}$ & $0,066^{* \star *}$ & $0,077^{* \star *}$ & $0,074^{\star \star \star}$ & $0,075^{\star \star \star}$ & $0,063^{\star \star \star}$ \\
\hline ACQTARGt-1 & $-0,084^{\star * *}$ & - & $-0,082^{* \star *}$ & $-0,070^{* \star *}$ & - & $-0,095^{\star \star \star}$ \\
\hline Firm controls included & yes & yes & yes & yes & yes & yes \\
\hline Bank controls included & yes & yes & yes & yes & yes & yes \\
\hline
\end{tabular}

We again base our discussion on Panel B. In terms of the short-run merger effects, an interesting heterogeneity between borrowers from acquiring and target banks now appears. For example, the results for the "All” sample indicate that borrowers of acquiring banks have a lower likelihood (-1.1\%) of losing their relationships than borrowers of nonmerging banks, while borrowers of target banks have a greater likelihood (+1.5\%) of being dropped (an exception to the latter result is the multiplerelationship regression in the panel B sample where the coefficient is not significant). Firms borrowing from both the acquiring and a target bank have a lower probability $(-10.3 \%)$ of losing their relationship than firms borrowing from nonmerging banks.

The longer run marginal effects of mergers provide further support for these results and appear to be more robust. Firms borrowing from an acquiring bank have a lower probability $(-2.1 \%)$ of losing their relationship during the six to eighteen months following mergers than borrowers of nonmerging banks. Firms borrowing from a target bank have a higher probability (+7.4\%) of losing their relationship than otherwise identical firms not borrowing from the target bank.

These results suggest, in line with Hypothesis 2a, that it is important to distinguish borrowers of target banks from borrowers of acquiring banks. Indeed, the result from Table 6 suggesting that borrowers of only one of the merging banks may be more 
likely to lose their relationship in the longer run does not tell the whole story. Borrowers of acquiring banks have a lower probability of losing their relationship with the consolidated bank, while borrowers of target banks have a higher probability of losing the relationship with the consolidated bank.

These results are also consistent with findings of Sapienza (2002) and Karceski et al. (2004), who report that borrowers from target banks in Italy and Norway, respectively, are more likely to lose their relationship. In contrast, however, neither of these studies finds the rate of termination of bank lending relationships for borrowers of acquiring banks to be much different from the rate for borrowers of nonmerging banks. In addition, both Sapienza (2002) and Karceski et al (2004) find the effects of mergers on target bank borrowers to be stronger for small than for large target banks. Although all of our mergers involve large target banks (and one merger involves a large and a medium-size target bank), we nevertheless observe strong effects of mergers on borrowers of target banks. We also find that mergers have immediate effects, although the effects are more robust in the longer run.

Finally, neither of the above studies treats separately firms borrowing from both the acquiring and target bank in a merger. Our results suggest that borrowing from both banks prior to a merger (overlap borrowers) results in a significantly lower probability of loss of relationship than borrowing from a single merging bank, in line with Hypothesis 2d.

\section{IV.3 Mergers and firm size}

Are small borrowers affected differently than large borrowers by bank mergers? We address this combination of Hypotheses 2a,b and c in Table 8, which reports the results of the interactions of firm size with the merger variables separately for target and acquiring bank borrowers. ${ }^{25}$

\footnotetext{
${ }^{25}$ We have also run similar regression interacting the merger variables with firm profitability; however, we obtained no significant results.
} 
Table 8: Panel regressions: interaction with firm size for acquirer and target banks

The dependent variable in each regression equals one if during the following year firm i loses its relationship with bank k. The reported coefficients are logit estimates of a marginal change in the independent variable on the probability of losing the lending relationship. All regressions include a constant term, firm industry dummies, and year dummies (not reported). Definitions of the variables are provided in Section III. *, **, *** denotes significance at the 10, 5, and 1\%-level, respectively (based on heteroskedastic-robust standard errors).

\begin{tabular}{|c|c|c|c|}
\hline & \multicolumn{3}{|c|}{ With merging bank fixed effects } \\
\hline & \multicolumn{3}{|c|}{ Sample } \\
\hline & All rel. & $\begin{array}{r}\text { Single } \\
\text { rels. }\end{array}$ & Multiple rels \\
\hline ACQUIREt & $0,123^{\text {*** }}$ & $0,043^{*}$ & $0,058^{*}$ \\
\hline TARGETt & $-0,122^{\star * \star}$ & $-0,186^{\star *}$ & $-0,139 \star \star \star$ \\
\hline ACQTARGt & $-0,429$ *** & - & $-0,361^{\star \star *}$ \\
\hline ACQUIREt-1 & $0,128^{\star * \star}$ & 0,032 & $0,180^{\star \star \star}$ \\
\hline TARGETt-1 & 0,029 & $-0,135^{\star \star *}$ & $0,159^{* * *}$ \\
\hline ACQTARGt-1 & $-0,316^{\star \star \star}$ & $-0,216$ & $-0,377^{\star \star}$ \\
\hline ACQUIREt $* \ln ($ ASSETF $)$ & $-0,010^{\star \star \star *}$ & $-0,004^{* *}$ & $-0,006^{\star \star}$ \\
\hline TARGETt * $\ln ($ ASSETF $)$ & $0,011^{\star \star \star}$ & $0,017^{\star \star \star}$ & $0,011^{\star \star \star}$ \\
\hline ACQTARGt * $\ln ($ ASSETF $)$ & $0,023^{* \star *}$ & - & $0,018^{* \star *}$ \\
\hline ACQUIREt-1 * $\ln ($ ASSETF $)$ & $-0,011^{\star * *}$ & $-0,004^{*}$ & $-0,015^{* *}$ \\
\hline TARGETt-1 * $\ln ($ ASSETF $)$ & $0,004^{*}$ & $0,017^{\star \star *}$ & $-0,007^{\star \star *}$ \\
\hline ACQTARGt-1*ln(ASSETF) & $0,018^{\star *}$ & 0,011 & 0,019 \\
\hline Firm controls & yes & yes & yes \\
\hline Bank controls & yes & yes & yes \\
\hline Bank dummies & yes & yes & yes \\
\hline
\end{tabular}

The differing relative effects of mergers on firms of differing sizes are reflected by the interaction of the merger variables with ACQUIRE*ASSETF. Interestingly, however, the sign of the total merger effect, as given by the sum of the merger variable and the interaction term (e.g., ACQUIRE + ACQUIRE*ASSETF), now differs in certain regressions for small and large firms. ${ }^{26}$ Because results differ according to the time period following the merger and according to the number of relationships (single vs. multiple) maintained by borrowers, we differentiate these cases in the discussion.

Acquiring banks and firm size. The interaction terms ACQUIREt*ASSETF for the short run indicate that large firms with single and multiple relationships are favoured by acquiring banks: large firms borrowing from the acquiring bank have a lower

\footnotetext{
${ }^{26}$ The coefficients on the noninteracted merger variables must now be interpreted as reflecting the effect of a merger for a firm with a zero value of assets. Despite the fact that some of the coefficients on these merger variables have changed signs relative to the regressions reported in Table 7, the estimated total marginal effects of mergers (as reflected by e.g., ACQUIRE + ACQUIRE*ASSETF) are the same as those implied by the coefficients in Table 8.
} 
probability than small firms of having their lending relationships terminated. The long run interaction of size and the acquiring bank variable is in line with the short run effects. In terms of the total merger effect for acquiring borrowers (given by ACQUIRE + ACQUIRE*ASSETF), in the short run small firms borrowing from acquiring banks have a higher probability of losing their relationship than nonmerging bank borrowers, while firms that are large enough have a lower probability. In the long run, smaller firms with multiple relationships borrowing from acquiring banks have a higher probability than nonmerging borrowers of losing their relationship, and large firms have a lower probability.

Target banks and firm size. In the short run, large borrowers of target banks have a higher probability than small borrowers of losing their relationship with the merged bank. This difference also holds in the long run for single relationship firms; however, for firms with multiple relationships, smaller borrowers of target banks are more likely than large borrowers to lose their relationship with the merged bank than larger borrowers at target banks.

The result that larger borrowers are more likely to maintain their relationships at acquiring banks is consistent with the hypothesis that mergers gives banks a greater comparative advantage in lending to large firms. However, the results for target bank borrowers are not consistent with this hypothesis. Namely, in the short run large borrowers of target banks have a higher probability than small borrowers of losing their relationship. One possible interpretation of the results for target borrowers is that larger firms and firms with multiple relationships have more alternative sources of finance than smaller, single relationship firms and, hence, lower switching costs. In the short run, borrowers of target banks with the lowest switching costs switch from the target bank (which may be required to adopt the credit policies of the acquirer) to other sources of finance. Borrower-initiated switching may be an important factor behind the higher relationship drop rate for borrowers of target banks in the short run, whereas bank-initiated terminations may become the driving force in the longer run. Indeed, Karceski et al (2004) report results that suggest that borrowers of target banks with lower estimated switching costs suffer less of a negative abnormal return from mergers than borrowers with higher switching costs. Larger firms and firms with multiple relationships are considered by Karceski et al. to have lower switching costs. 
IV.4 Robustness: Individual merger regressions and other robustness issues

As a check on the panel regression results, we also run regressions for each individual merger (using the same sample of firms as for the panel regressions), and we run separate regressions for the short-run and long-run effects. ${ }^{27}$ Table 9 presents the results of the test for the effects of mergers on firms borrowing from merging banks versus nonmerging banks. This table reports the number of mergers for which the coefficients on the different merger variables were statistically significant and of a given sign. Because the firm and bank control variables yield results for each merger that are similar to those reported in Table 6 for the panel regressions, we report here only the results for the merger variables.

\section{Table 9: Individual merger regressions: impact on lending relationships}

The dependent variable in each regression equals one if during the following year firm i loses its relationship with bank k. Numbers in each cell give the number of mergers for which the variable was statistically significant with a particular sign.

\begin{tabular}{|l|l|l|l|l|}
\hline & & \multicolumn{3}{|c|}{ Sample } \\
\hline Independent Variable & $\begin{array}{l}\text { Sign of } \\
\text { coefficient }\end{array}$ & $\begin{array}{l}\text { All } \\
\text { firms }\end{array}$ & $\begin{array}{l}\text { Single } \\
\text { rel }\end{array}$ & $\begin{array}{l}\text { Multiple } \\
\text { rels. }\end{array}$ \\
\hline Short run effects & & & & \\
\hline MERG1t & - & 2 & 3 & 2 \\
\hline & + & & & 1 \\
\hline MERG2t & - & 3 & - & 3 \\
\hline & + & & & \\
\hline Long run effects & & & & \\
\hline MERG1t-1 & - & 1 & $1^{*}$ & 2 \\
\hline & + & 1 & 1 & \\
\hline MERG2t-1 & - & 2 & - & 3 \\
\hline & + & & & \\
\hline
\end{tabular}

Significant at $10 \%$ level.

Table 9 provides support for the result that firms borrowing from merging banks have lower probabilities in the short run of losing their relationship. This result also appears to hold in the long run, although the coefficient for MERG1t becomes significantly positive for the multiple relationship sample for one merger.

\footnotetext{
${ }^{27}$ These regressions are more comparable to our panel regressions without bank fixed effects than with.
} 
Table 10 reports the results of the individual merger regressions for target and acquirer bank borrowers. This table reveals some heterogeneity in the short run effects of mergers; however, the long run effects provide stronger support for the results reported in the panel regressions. The differing effects of mergers on acquiring and target borrowers appear to be more consistent across individual mergers for firms with multiple relationships than for firms with single relationships.

\section{Table 10: Individual merger regressions: acquirer and target effects}

The dependent variable in each regression equals one if during the following year firm i loses its relationship with bank $\mathrm{k}$. Numbers in each cell give the number of mergers for which the variable was statistically significant with a particular sign.

\begin{tabular}{|l|l|l|l|l|}
\hline & & \multicolumn{3}{|c|}{ Sample } \\
\hline Independent Variable & $\begin{array}{l}\text { Sign of } \\
\text { coefficient }\end{array}$ & $\begin{array}{l}\text { All } \\
\text { firms }\end{array}$ & $\begin{array}{l}\text { Single } \\
\text { rel }\end{array}$ & $\begin{array}{l}\text { Multiple } \\
\text { rels. }\end{array}$ \\
\hline Short run effects & & & & \\
\hline ACQUIREt & - & 3 & 3 & 2 \\
\hline & + & & & 1 \\
\hline TARGETt & - & & 2 & \\
\hline & + & 1 & 1 & 2 \\
\hline ACQTARGt & - & 3 & - & 3 \\
\hline & + & & - & \\
\hline Long run effects & & & & \\
\hline ACQUIREt-1 & - & 2 & 2 & $3^{*}$ \\
\hline & + & & & \\
\hline TARGETt-1 & - & \multicolumn{2}{|l|}{1} & 2 \\
\hline & + & 1 & $2^{*}$ & 2 \\
\hline ACQTARGt-1 & - & 2 & - & 3 \\
\hline & + & & & \\
\hline
\end{tabular}

One regression significant at $10 \%$ level; others significant at $5 \%$ level or lower.

Our definition of a lending relationship is based on utilised exposures and includes firms with zero utilised exposures but which are nevertheless reported by the bank in the credit register. Because firms with zero utilised exposures might be expected to be more likely to "exit" the data set and have their relationship dropped, and to make sure that these firms are not driving our results we reran our panel regressions excluding all firms with zero utilised exposures. The results remain very similar and are therefore not reported. 


\section{Conclusion}

This paper studies the impact of bank consolidation on bank lending relationships of small and medium-size firms, using information from individual loan contracts in Belgium. We estimate the effect of bank mergers on borrowers' ability to maintain their bank relationships and to continue to tap bank credit. The paper represents one of a very small number of papers relying on firm-level loan contract data to study the effects of bank mergers. In addition, it considers mergers in an environment where firms maintain relatively few relationships and banking markets are highlyconcentrated, a number of features that have not been present in other studies but are typical for a number of countries.

Our results indicate that mergers have effects in the short run as well as the longer run. When we distinguish between firms borrowing from merging banks and those borrowing from nonmerging banks, we find that merging bank borrowers are significantly less likely to see their lending relationship terminated than nonmerging bank borrowers following a merger. When we distinguish between borrowers of acquiring and target banks, we find that borrowers at target banks are more likely to see their relationship terminated, whereas borrowers of acquiring banks are less likely to have their relationship dropped following a merger. These differential effects begin appearing even in the short run, but they become more robust in the longer run. In addition, our results on acquiring bank borrowers appear to be stronger than those reported in empirical work for other countries.

Similar to other studies, we find heterogeneous effects of bank mergers for large versus small firms. The effects, however, also differ for large firms borrowing from acquiring banks compared with large firms borrowing from target banks, and for target bank borrowers with single versus multiple lending relationships. Whereas large borrowers are favored by acquiring banks, large borrowers of target banks are more likely in the short run to have their lending relationship severed.

One possible interpretation of the results for target borrowers (and a focus of our ongoing work) is that borrowers of target banks with low switching costs, including some large borrowers with multiple lending relationships, may voluntarily switch 
banks immediately following the merger. Borrowers with high switching costs are forced to stay with the merging bank. Examination of changes in loan volumes for target borrowers with multiple relationships should enable us to determine if these borrowers compensate for the severed relationship with the merged bank by borrowing more from the other banks with which a relationship already exists.

Because switching costs are likely to be higher for borrowers with single relationships than for borrowers with multiple relationships, we run separate regressions for firms with single and with multiple relationships, in addition to running regressions for all firms taken together. Although results for these two groups are similar, a few differences appear, such as those for target borrowers noted above. Another difference emerges in the effect of firm age on the probability of dropping a lending relationship. Younger firms with single relationships have more stable lending relationships than older firms, whereas younger firms with multiple relationships have less stable lending relationships than older firms. Finally, at the level of merging bank versus nonmerging bank borrowers, single relationship borrowers of merging banks have a higher probability in the longer run of losing their relationships with the merged bank than do borrowers of nonmerging banks. In contrast, multiple relationship borrowers have a lower probability of losing their relationship with the merged bank.

Finally, we find that firms borrowing from two of the merging banks are substantially less likely to lose their relationship with the consolidated bank than other borrowers. One might ask whether this result simply reflects the relationship with the acquiring bank, which also would imply that the firm has a lower probability of losing the relationship. The effect for these overlap borrowers, however, is much stronger than that for acquiring bank borrowers only. This suggests that informational gains arise from the pooling of information of the merging banks that may not appear when only one of the merging banks was previously lending to the firm.

Although we have shown that mergers have significant effects on the drop rate of lending relationships with SMEs, we have not yet been able to investigate the extent to which borrowers continuing on with the merged bank may benefit from or be harmed by the merger. Ideally, we would need data on interest rates in order to study these effects. While the Belgian credit register data do not contain interest rates, we 
do have information on loan volumes, from which we may be able to make some inferences about loan terms. Part of our ongoing work involves an investigation of the impact of mergers on borrowers' loan volumes. 


\section{REFERENCES}

A. Berger, R. Demsetz and P. Strahan (1999), The consolidation of the financial services industry: causes, consequences, and implications for the future, Journal of Banking and Finance, 23, 135-194.

A. Berger, N.Miller, M. Petersen, R. Rajan and J. Stein (2004), Does function follow organizational form? Evidence from the lending practices of large and small banks., forthcoming in Journal of Financial Economics.

A. Berger and G. Udell (1996), Universal Banking and the future of small business lending, in A. Saunders and I. Walter, (eds) Financial System Design: The case for universal banking (Irwin Publishing, Homewood, IL)

D. Bernheim and M. Whinston (1990), Multimarket contact and collusive behaviour, Rand Journal of Economics, 21, pp. 1-26.

E. Bonaccorsi di Patti and G. Gobbi (2003), The effects of bank mergers on credit availability: evidence from corporate data, Banca d'Italia Temi di discussione 479.

J. Bouckaert and H. Degryse (2004), Softening competition by inducing switching in credit markets, Journal of Industrial Economics LII, 27-52.

N. Cetorella and M. Gambera (2001), Banking market structure, financial dependence, and growth: International evidence from industry data, Journal of Finance 56, 617-648.

G. Chionsini, A. Foglia, and P. Marullo-Reedtz (2004), Bank mergers, diversification and risk, mimeo, Bank of Italy.

R. Cole, L. Goldberg, and L. White (2004), Cookie-cutter versus character: the micro structure of small business lending by large and small banks, Journal of Financial and Quantitative Analysis 39.

E. de Bodt, F. Lobez, and J. C. Statnik, 2001, Credit Rationing, Customer Relationship, and the Number of Banks: An Empirical Analysis, (University of Lille, Lille).

E. Detragiache, P. G. Garella, and L. Guiso, 2000, Multiple versus Single Banking Relationships: Theory and Evidence, Journal of Finance 55, 1133-1161.

H. Degryse, and P. Van Cayseele (2000), Relationship lending within a bank-based system: Evidence from European Small Business Data, Journal of Financial Intermediation 9, 90109.

H. Degryse, N. Masschelein, and J. Mitchell (2004), "Belgian Firms, Bank Finance, and Determinants of Bank Lending Relationships," Financial Stability Review, National Bank of Belgium, June.

H. Degryse and S. Ongena (2004), Distance, Lending Relationships and Competition, forthcoming in Journal of Finance.

E. Detragiache, P. Garella and L. Guiso (2000), "Multiple versus Single Banking Relationships: Theory and Evidence" Journal of Finance, 55, 1133-1161

M. Dietsch and V. Golitin-Boubakari (2002), L'évolution des relations banques-entreprises dans les années 1990, in Bulletin de la Commission Bancaire n² 27, Novembre 2002, p 74-107.

L.A. Farinha and J. Santos (2002), "Switching from single to multiple bank lending relationships: determinants and implications, Journal of Financial Intermediation, 11,124-151.

D. Focarelli, F. Panetta, and C. Salleo (2002), Why do banks merge?, Journal of Money, Credit and Banking, 34, 1047-1066.

R. Hauswald and R. Marquez (2003), Information Technology and Financial Services Competition, Review of Financial Studies 16, 921-948.

J.F. Houston, C.M. James and D. Ryngaert (2001), Where do merger gains come from? Bank mergers from the perspective of insiders and outsiders, Journal of Financial Economics 60, 285-331.

J. Karceski, S. Ongena and D. Smith (2004), The impact of bank consolidation on commercial borrower welfare, forthcoming in Journal of Finance. 
P. Klemperer (1995), Competition when consumers have switching costs: An overview with applications to Industrial Organization, Macroeconomics and International Trade, Review of Economic Studies 62, 515)539.

M. Kim, D. Kliger and B. Vale (2003), Estimating Switching Costs: the case of banking, Journal of Financial Intermediation, 12, pp. 25-56.

L. Mester (1987), Multiple market contact between savings and loans, Journal of Money, Credit and Banking, 19, 538-549.S. Ongena and D. Smith (2000), What determines the number of bank relationships? Cross-country evidence, Journal of Financial Intermediation, 9, 26-56.

F. Panetta, P. Schivardi and M. Shum (2004), Do mergers improve information? Evidence from the Loan Market, mimeo, Bank of Italy.

J. Peek and E.S. Rosengren (1996), Small business credit availability: How important is size of lender?, in A. Saunders and I. Walters (eds) Financial System Design: The case for Universal Banking, Homewood, IL: Irwin Publishing.

M.A. Petersen and R.G. Rajan (1994), The benefits from lending relationships: evidence from small business data, Journal of Finance, 49, 3-37.

M.A. Petersen and R.G. Rajan (1995), "The Effect of Credit Market Competition on Lending Relationships", Quarterly Journal of Economics, 110, pp. 406-443.

S.W. Salant, S. Switzer, and R.J. Reynolds (1983), Losses due to mergers: the effect of an exogenous change in industry structure on Cournot-Nash equilibrium, Quarterly Journal of Economics 98, pp. 185-199.

J. Scott and W.C. Dunkelberg (2003), Bank Mergers and Small Firm Financing, forthcoming in Journal of Money, Credit and Banking.

P. Sapienza (2002), "The Effects of Banking Mergers on Loan Contracts", Journal of Finance, 57, pp. 329-367.

J. Stein (2002), Information Production and Capital Allocation: Decentralized versus hierarchical firms, Journal of Finance 57, 1891-1921.

P.E. Strahan and J.P. Weston (1998), Small Business Lending and the changing structure of the banking industry, Journal of Banking and Finance 22, 821-845.

G. Udell (1989), Loan quality, commercial loan review and loan officer contracting, Journal of Banking and Finance 13, 367-382.

E. Von Thadden (2004), Asymmetric information, bank lending and implicit contracts: The winner's curse, Finance Research Letters, 1. 
Appendix A

Variable definitions

\begin{tabular}{|c|c|}
\hline \multicolumn{2}{|c|}{ Firm control variables } \\
\hline AGEF & Age of the firm in years \\
\hline ASSETF & Total book value of assets of the firm, expressed in $2002 €$ \\
\hline ROAF & EBIT over assets \\
\hline LEVERAGE & Book value of debt over assets \\
\hline NEGEQ & Dummy that takes value 1 if firm has negative equity \\
\hline RECBALANCE & $\begin{array}{l}\text { Dummy that takes value } 1 \text { for firms with balance sheet } \\
\text { available in at least one of the two years prior to year in } \\
\text { which credit was granted }\end{array}$ \\
\hline YOUNG & $\begin{array}{l}\text { Dummy that takes value } 1 \text { for firms younger than } 3 \text { years and } \\
\text { whose balance sheet covers less than } 12 \text { months of data }\end{array}$ \\
\hline \multicolumn{2}{|c|}{ Bank control variables } \\
\hline ASSETB & Total assets of the bank, expressed in $2002 €$ \\
\hline ROAB & Total return on assets \\
\hline BADLOANSB & Non-performing loans over total loans \\
\hline OPCOSTB & Operating costs over total assets \\
\hline LIQB & $\begin{array}{l}\text { (Cash + net position in the interbank market + short term } \\
\text { securities' portfolio + government bonds) over assets }\end{array}$ \\
\hline \multicolumn{2}{|l|}{ Merger variables } \\
\hline $\mathrm{MERG}_{\mathrm{kt}}$ & $\begin{array}{l}\text { Dummy }=1 \text { if firm borrowing from bank } k \text { which was } \\
\text { involved in a merger occurring during } 12 \text { months following } \\
\text { time } t \text { and if firm not borrowing from any of the other } \\
\text { merging banks }\end{array}$ \\
\hline MERG2 $2_{\mathrm{kt}}$ & $\begin{array}{l}\text { Dummy }=1 \text { if firm borrowing from bank } k \text { which was } \\
\text { involved in a merger occurring during } 12 \text { months following } \\
\text { time } t \text { and if firm borrowing from at least one of the other } \\
\text { merging banks }\end{array}$ \\
\hline ACQUIRE $_{\mathrm{kt}}$ & $\begin{array}{l}\text { Dummy }=1 \text { if firm borrowing from bank } k \text { which was the } \\
\text { acquiring bank in a merger occurring during } 12 \text { months } \\
\text { following time } t \text { and if firm not borrowing from any of the } \\
\text { other merging banks }\end{array}$ \\
\hline TARGET $_{\mathrm{kt}}$ & $\begin{array}{l}\text { Dummy }=1 \text { if firm borrowing from bank } k \text { which was a } \\
\text { target bank in a merger occurring during } 12 \text { months } \\
\text { following time } t \text { and if firm not borrowing from any of the } \\
\text { other merging banks }\end{array}$ \\
\hline ACQTARG $_{\mathrm{kt}}$ & $\begin{array}{l}\text { Dummy }=1 \text { if firm borrowing from bank } k \text { which was } \\
\text { involved in a merger occurring during } 12 \text { months following } \\
\text { time } t \text { and if firm was borrowing from the acquiring and a } \\
\text { target bank }\end{array}$ \\
\hline MERG1 $1_{\mathrm{k}, \mathrm{t}-1}$ & $\begin{array}{l}\text { Dummy }=1 \text { if firm borrowing from bank } k \text { which was } \\
\text { involved in a merger occurring between time } t-1 \text { and } t \text { and if } \\
\text { firm not borrowing from any of the other merging banks }\end{array}$ \\
\hline MERG2 $2_{\mathrm{k}, \mathrm{t}-1}$ & $\begin{array}{l}\text { Dummy }=1 \text { if firm borrowing from bank } k \text { which involved in } \\
\text { a merger occurring between time } t-1 \text { and } t \text { and if firm was } \\
\text { borrowing from at least one of the other merging banks }\end{array}$ \\
\hline ACQUIRE $_{\mathrm{k}, \mathrm{t}-1}$ & $\begin{array}{l}\text { Dummy }=1 \text { if firm borrowing from bank } k \text { which was the } \\
\text { acquiring bank in a merger occurring between time } t-1 \text { and } t\end{array}$ \\
\hline
\end{tabular}




\begin{tabular}{|l|l|}
\hline & $\begin{array}{l}\text { and if firm not borrowing from any of the other merging } \\
\text { banks }\end{array}$ \\
\hline TARGET $_{\mathrm{k}, \mathrm{t}-1}$ & $\begin{array}{l}\text { Dummy } 1 \text { if firm borrowing from bank } k \text { and bank } k \text { was a } \\
\text { target bank in a merger occurring between time } t-1 \text { and } t \text { and } \\
\text { if firm was not borrowing from any of the other merging } \\
\text { banks }\end{array}$ \\
\hline ACQTARG $_{\mathrm{t}-1}$ & $\begin{array}{l}\text { Dummy } 1 \text { if firm borrowing from bank } k \text { which was } \\
\text { involved in a merger occurring between time } t-1 \text { and } t \text { and if } \\
\text { firm was borrowing from both the acquirer and a target bank }\end{array}$ \\
\hline Other variables & \\
\hline UR & $\begin{array}{l}\text { Dummy that takes value } 1 \text { if firm has a single lending } \\
\text { relationship }\end{array}$ \\
\hline
\end{tabular}

